\title{
Sustainable Agriculture: Towards Holistic Overview
}

\author{
T. Alshaal and H. El-Ramady
}

Soil and Water Department, Faculty of Agriculture, Kafrelsheikh University, Egypt

\begin{abstract}
t is well known that, agriculture is an important industry that helped and provided the humanity with the necessary food, feed, fibre and fuel from the ancient centuries. So, a crucial role for agriculture and its sustainability should be identified. Concerning the sustainable agriculture, it means how to supply the humans with previous essential living supplies without any compromising of needs for future generations. This needs definitely the integration among the environment and its quality, economic profitability, social and economic equity as well as maintaining or conservation of the water and land resources. Moreover, farming systems should use fewer inputs and natural resources without any reducing of agricultural yields in order to reach economic profitability, the safety of the environment and social fairness. Therefore, this review will focus on the sustainability of the agriculture from a holistic overview.
\end{abstract}

Keywords: Sustainable agriculture, Soils, Water, Energy, Kafrelsheikh University.

\section{Introduction}

Sustainable agriculture can be defined as an integrated system for production practices belonging both plants and animals for a long term. It includes also the study of different relationships between both organisms and their environment (Lichtfouse et al., 2009, Lal, 2009, Chen and Zhang, 2015 and Sarkar et al., 2017). It is a type of farming in which sustainable ways should be based on the understanding of ecosystem services. The phrase of sustainable agriculture was coined by the Australian agricultural scientist Gordon McClymont. The conventional agriculture leads to several problems for the environment and its resources including the agro-practices (e.g., irrigation, tillage, fertilization and drainage). Soil degradation, erosion, salinization, nutrients depletion, and more are common problems resulted from conventional agriculture. Therefore, an urgent need for sustainable agriculture is expected to achieve the sustainable agroecosystem through different holistic dimensions (Srivastava et al., 2016). So, several publications including books focus on this important issue such as Leakey (2017) and Nhamo et al. (2018).

Concerning subjects related to sustainable agriculture, several books have been published during last few years including using of nanotechnology (e.g., Ranjan et al., 2017), the interactions between plants and microbes (Choudhary et al., 2016), using organic farming approach (Bellon \& Penvern, 2014 and Nandwani, 2016), using biotechnology approach (e.g., Maheshwari, 2014, Solaiman et al., 2014 and Meena et al., 2016), new approaches in fertilization (Maheshwari, 2014, Solaiman et al., 2014 and Tei et al., 2017), soil remediation (Arora et al., 2017, Saha et al., 2017 and Singh \& Seneviratne, 2017b), irrigation management (Satoh and Aboulroos, 2017) and agroenvironmental approaches for sustainability (Singh \& Seneviratne, 2017a,b and Lichtfouse, 2017). Therefore, all agricultural sciences should be sustained from both the national and global point of view seeking for the targeted sustainable development.

\section{Journal of Sustainable Agricultural Sciences}

The Journal of Sustainable Agricultural Sciences (JSAS) is the official journal of Faculty of Agriculture, Kafrelsheikh University in Egypt. This journal is established since September 1975 and called formerly as Journal of Agriculture Research Kafrelsheikh University. JSAS is also an international, double-blind peer-reviewed, open-access multidisciplinary journal. It is a scientific journal dedicated to publish outstanding research on all aspects of agricultural sciences with special emphasis on sustainability (Table 1). Due to previous important information, scope of this journal is wide and embraces accounts of recent original research on any aspect of the 
agricultural sciences and major journal topics currently include:

- Agricultural engineering,

- Livestock sciences

- Agronomy, and crop sciences

- Plant sciences, pathology, protection and breeding

- Horticulture sciences

- Food technology and dairy sciences

- Soil and water sciences, and agro-ecosystems

- Aquaculture, aquatic ecology and fishery

- Biotechnology, biological engineering, and genetics

- Biodiversity, bio-resources and sustainability of agricultural and food systems

- Economic, social, and philosophical aspects of sustainable agriculture

- Environmental impacts of agriculture and desertification

- Irrigation, water management, and land use

- Agricultural waste management, and recycle technology

- Economic entomology, pesticides and integrated pest management,

- Organic and biodynamic farming, sustainable energy use

- Agriculture and global climate change

- Agro-ecosystems and natural environments

- Integrated solutions for environmental goal and agricultural sustainability

- Future projections, options, policies, and indicators of sustainability

- Air, soil, and water pollutants and health

- Precision farming and soil biology

- Soilless, organic and other alternative systems of farming technology.

\section{Acknowledgments}

The Editorial Board of JSAS thanks all previous board members in Journal of Agriculture
TABLE 1. Major changes in the journal of sustainable agricultural sciences in 2017.

\begin{tabular}{|c|c|c|}
\hline Items & Before renovation & Current situation (or \\
\hline \multirow{4}{*}{ Title } & Journal of & The Journal \\
\hline & Agriculture & of Sustainable \\
\hline & Research & Agricultural \\
\hline & Kafrelsheikh Uni. & Sciences (JSAS) \\
\hline Starting year & September 1975 & April 2017 \\
\hline Field Editors & 7 & 25 \\
\hline Pre-selection Committee & None & 14 Associate editors \\
\hline \multirow{3}{*}{ Topics } & Conventional & Sustainable \\
\hline & Agriculture & Agricultural \\
\hline & Research & Sciences \\
\hline Research article format & No size limit & Short articles \\
\hline Language & $75 \%$ English & $100 \%$ English \\
\hline Pre-selection rejection & 0 & 50 \\
\hline $\begin{array}{c}\text { Research articles per } \\
\text { year }\end{array}$ & 79 & 44 \\
\hline Review articles per year & 3 & 12 \\
\hline Type of articles & Local & $\begin{array}{l}\text { International with } \\
\text { DOI }\end{array}$ \\
\hline Acceptance delay & 4-6 months & 2-3 months \\
\hline Article management & Hardcopy, post & $\begin{array}{c}100 \% \text { electronic, } \\
\text { pdfs }\end{array}$ \\
\hline
\end{tabular}

Research Kafrelsheikh University as well as authors, peer-reviewers and field editors.

\section{References}

Arora, S., Singh, A.K. and Singh, Y.P. (2017) Bioremediation of Salt Affected Soils: An Indian Perspective. Springer International Publishing AG, DOI 10.1007/978-3-319-48257-6

Bellon, S. and Penvern, S. (2014) Organic Farming, Prototype for Sustainable Agricultures: Prototype for Sustainable Agricultures. Springer Science + Business Media Dordrecht, DOI 10.1007/978-94007-7927-3

Chen H.G. and Zhang, Y.H.P. (2015) New biorefineries and sustainable agriculture: Increased food, biofuels, and ecosystem security. Renewable and Sustainable Energy Reviews, 47, 117-132

Choudhary, D.K., Varma, A. and Tuteja, N. (2016) Plant-Microbe Interaction: An Approach to Sustainable Agriculture. Springer Nature Singapore Pte Ltd, DOI 10.1007/978-981-10-2854-0

Lal, R. (2009) Soils and Sustainable Agriculture: A Review. In: E. Lichtfouse et al. (Ed.), Sustainable Agriculture, DOI: 10.1007/978-90-481-2666-8 3, 15 c Springer Science + Business Media B.V. - EDP Sciences 2009. Reprinted with permission of EDP Sciences from Lal, Agron. Sustain. Dev. 28 (2008) 57-64. DOI: 10.1051/agro:2007025

Leakey, R. (2017) Multifunctional Agriculture: Achieving Sustainable Development in Africa. ISBN: 978-0-12-805356-0. Academic Press, Elsevier B.V. 
Lichtfouse, E. (2017) Sustainable Agriculture Reviews. Sustainable Agriculture Reviews Series, vol. no. 22, Springer International Publishing Switzerland, DOI 10.1007/978-3-319-48006-0

Lichtfouse, E., Navarrete, M., Debaeke, P. Souchère, V and Alberola, C. (2009) Sustainable Agriculture. Springer Science + Business Media B.V., DOI 10.1007/978-90-481-2666-8

Maheshwari, D.K. (2014) Composting for Sustainable Agriculture. Sustainable Development and Biodiversity Series, vol. 3, Springer International Publishing Switzerland, DOI 10.1007/978-3-31908004-8

Maheshwari, D.K. (2014) Bacterial Diversity in Sustainable Agriculture. Sustainable Development and Biodiversity Series, vol. 1, Springer International Publishing Switzerland, DOI 10.1007/978-3-319-05936-5

Meena, V.S., Maurya, B.R., Verma, J.P. and Meena, R.S. (2016) Potassium Solubilizing Microorganisms for Sustainable Agriculture. Springer India, DOI 10.1007/978-81-322-2776-2

Nandwani, D. (2016) Organic Farming for Sustainable Agriculture. Sustainable Development and Biodiversity Series, vol. 9, Springer International Publishing Switzerland, DOI 10.1007/978-3-31926803-3

Nhamo, N, Chikoye, D. and Gondwe, T. (2018) Smart Technologies for Sustainable Smallholder Agriculture: Upscaling in Developing Countries. Academic Press, Elsevier B.V. ISBN: 978-0-12810521-4

Ranjan S., Dasgupta, N. and Lichtfouse, E. (2017) Nanoscience in Food and Agriculture 4. Sustainable Agriculture Reviews Series, vol. 24, Springer International Publishing AG, DOI 10.1007/978-3319-53112-0

Saha, J.K., Selladurai, R., Coumar, M.V., Dotaniya, M.L., Kundu, S. and Patra, A.K. (2017) Soil Pollution - An Emerging Threat to Agriculture. Environmental Chemistry for a Sustainable World Series, vol. 10, DOI 10.1007/978-981-10-4274-4, Springer Nature Singapore Pte Ltd

Sarkar, S.F., Poon, J.S., Lepage, E., Bilecki, L. Girard, B. (2017) Enabling a Sustainable and Prosperous Future through Science and Innovation in the Bioeconomy at Agriculture and Agri-Food Canada. New Biotechnology (In Press).

Satoh, M. and Aboulroos, S. (2017) Irrigated Agriculture in Egypt: Past, Present and Future. Springer International Publishing Switzerland, DOI 10.1007/978-3-319-30216-4
Singh, J.S. and Seneviratne, G. (2017a) AgroEnvironmental Sustainability: volume 1: Managing Crop Health. Springer International Publishing AG, DOI 10.1007/978-3-319-49724-2

Singh, J.S. and Seneviratne, G. (2017b) AgroEnvironmental Sustainability: volume 2: Managing Environmental Pollution. Springer International Publishing AG DOI 10.1007/978-3-319-49727-3

Solaiman, Z.M., Abbott, L.K. and Varma, A. (2014) Mycorrhizal Fungi: Use in Sustainable Agriculture and Land Restoration. Soil Biology Series, vol. 41, Springer-Verlag Berlin Heidelberg, DOI 10.1007/978-3-662-45370-4

Srivastava, P., Singh, R., Tripathi, S. and Raghubanshi, A.S. (2016) An urgent need for sustainable thinking in agriculture- An Indian scenario. Ecological Indicators, 67, 611-622

Tei, F., Nicola, S. and Benincasa, P. (2017) Advances in Research on Fertilization Management of Vegetable Crops. Advances in Olericulture Series, Springer International Publishing AG, DOI: 10.1007/978-3319-53626-2

(Received 26/4/2017; accepted 1 / 7/2017) 